TEACHING JACOBITISM

\section{FOR THE TWENTY-FIRST CENTURY}

Kirsteen M. MacKenzie

Professional Historian
Teaching History 46(2)

DOI: $10.33043 /$ TH.46.2.20-27

(C) 2021 MacKenzie.

Distributed with CC BY-NC-ND 4.0 License.

For many students in my Jacobite course, the attraction of the recent television series, Outlander, lay in the central love story between Claire Randall, a nurse from the Second World War and her Jacobite love interest Jamie Fraser. ${ }^{1}$ I, however, was more drawn to the story of Claire Randall's husband Frank Randall, an Oxford professor of history who later accepts a post in the United States. This part of the story is set in the 1940s. The history profession Frank inhabits is elite, with a closed structure consisting of age-old rituals and rooms filled with old, white men. Frank, like many of his contemporaries at that time, conducted lectures, held seminars, and gave conference papers to students from privileged backgrounds in a face-to face environment. In one particular and poignant scene, Claire, a highly intelligent woman in her own right, feels ostracised and alienated from Frank Randall's colleagues who see her simply as the "wife" whose role is to stay in the background and stay at home. ${ }^{2}$ Watching this scene brought into sharp focus what historians used to be, and it made me reflect upon what historians are now and the potential for our role in the future. The emergence of public history, digital humanities, and online teaching have undoubtably had an impact on how we teach eighteenth century studies, and these developments would have seemed alien to historians in the 1940s. My own journey in teaching and developing a Jacobite course from 2015 to 2021 is a microcosm of these evolutionary changes in practice.

Designed in 2015 as a face-to-face seminar, the purpose of my course, "Jacobites: War, Exile, and the Politics of Succession in Britain and Ireland 1688-1788," was to introduce undergraduate students to the various Jacobite risings which had taken place in Britain and Ireland between 1689 and 1746. I had envisioned that I would be teaching a mainly knowledge-based course for students in the final years of their undergraduate degree. The first series of Outlander had already aired in the United Kingdom, and the Outlander phenomenon was fast becoming a reality as tourists flocked to Scotland. ${ }^{3}$ This influx of interest in Jacobite history spilled over into my Jacobite course as it became oversubscribed. Classes consisted of a wide range of nationalities and skills; a number of students who were fans of the show enrolled in the course purely out of interest. These students were studying for degrees outside the arts and humanities and never intended to embark on any kind of historical studies in the long term. I was very happy to accept these students in my course, but, as an instructor, I had the growing realization that I would have to outline the skills of the historians' craft to a much wider audience than I had initially anticipated.

Since 2015 there has been a significant shift in what I teach, how I teach, and how I see my future as a teacher of history in higher education. The purpose of this paper is to show this evolutionary process in practice and to demonstrate how a skills-based approach to historical thinking and the use of new technologies in the classroom can transform history courses, making them more attractive and beneficial for students. First, I outline key moments in this evolutionary process and emphasize how I incorporated skill-based tasks within the traditional classroom to challenge knowledge-based teaching. I then discuss how I used Twitter in my class, enabling students to interact in real time with leading experts in the field of Jacobite studies. Moving on to

\footnotetext{
${ }^{1}$ Outlander is a historical drama based on a novel series. It follows the experiences of a military nurse in Scotland who, in 1945, finds herself transported to 1743 .

${ }^{2}$ Sony Pictures Television, Outlander, “The Battle Joined," Season 3 Episode 1 (2017), IMDB entry https://www.imdb.com/title/ $\underline{\mathrm{tt} 5791266 / \text { ?ref }=\mathrm{ttep} \text { ep1 }}$

${ }^{3}$ Sony Pictures Television, Outlander, Season 1 (2014), IMDB entry https://www.imdb.com/title/tt3006802/episodes?season=1; Erika Mailman, "The Outlander Effect: The Popular Book and TV Series is Increasing Travel to These Scottish Sites," The Washington Post 14 February 2020, https://www.washingtonpost.com/lifestyle/travel/the-outlander-effect-the-popular-book-andtv-series-is-increasing-travel-to-these-scottish-sites/2020/02/13/900a2dfc-4c26-11ea-b721-9f4cdc90bc1c_story.html; BBC News, "Outlander Tourism Effect a Double-Edged Sword," 15 February 2020, https://www.bbc.co.uk/news/uk-scotland-highlandsislands-51488784
} 
recent developments, I examine the challenges and opportunities in moving from a face-to-face module to a digital module. I conclude by reflecting on how these developments are changing the teaching of eighteenthcentury history today.

\section{A Skills Based Approach to History Teaching}

Sam Wineburg has called historical thinking "an unnatural act," recognizing it "is neither a natural process nor something which springs automatically from psychological development." ${ }^{4}$ Indeed, we know this ourselves as history lecturers because at one time, we were the students sitting in class reading primary sources and spending time in the library grappling with the historiography. We have developed our skills in close reading in a variety of different contexts and by using various sources over an extensive number of years. We know that it takes practice and dedication to sharpen our critical thinking skills. However, as Stéphane Lévesque has argued, history teachers have failed to articulate and communicate to students in the classroom the specific skills that historians use. Most courses are driven by the need to know the subject matter rather than focusing on the skills that enable students to analyze the subject matter. Lendol Calder and Tracy Steffes have argued, ${ }^{5}$ similar to the logic of Wineburg and Lévesque, how favorable a shift in how we teach history in the university classroom would be, putting an emphasis on skills rather than content. Lévesque has clearly articulated the key skill sets which historians use to enable critical thinking when examining historical material. Historians evaluate and decide what are the most important events in the past, examine and assess change and continuity through time, measure and discuss the forces of progress and decay, and engage in the close reading, contextualizing, and corroboration of evidence. Lastly, historians practice historical empathy: We attempt to understand past actors without engaging in direct moral judgement through an imagined recreation and interpretation of the social values of the time period. ${ }^{6}$ In the United Kingdom, these skills have been articulated in the subject benchmark statement for history, which defines historians' skills and the qualities of mind which underpin all history courses at UK universities. ${ }^{7}$

As I was preparing to teach my course on the Jacobites in the summer of 2015, I was already aware of the argument that we should move towards a skill-based approach to teaching, which encourages students to be more active in their learning. ${ }^{8}$ There were opportunities for me to put into practice a skills-based approach in class. These practice and skill-based approaches were undertaken in real time during class discussions and as part of the students' continuous assessment, where they interacted with peers in the classroom. During the period of the course, there were three notable skills-based approach activities for the students to participate in. The first activity focused on the students' ability to assess primary evidence within a wider historiographical context. This involved the students focusing on the skill of corroborating historical evidence amidst conflicting interpretations by historians. The second activity focused on developing a sense of historical empathy through the reassessment of the Duke of Cumberland and his men's actions in the aftermath of Culloden. The third activity in the classroom intended to disrupt the students' notion of progress and decline at the end of the Jacobite movement. I did this by asking students to act out the famous court case of Knight v. Wedderburn. This

\footnotetext{
${ }^{4}$ Sam Wineburg, Historical Thinking and Other Unnatural Acts: Charting the Future of Teaching the Past (Philadelphia: Temple University Press, 2001), 7.

${ }^{5}$ Lendol Calder and Tracy Steffes, "Measuring College Learning in History," in Improving Quality in American Higher Education: Learning Outcomes and Assessments for the $21^{\text {st }}$ Century, eds. Richard Arum, Josipa Roksa, and Amanda Cook (San Francisco, CA: Jossey-Bass, 2016, 40.

${ }^{6}$ Stephane Levesque, Thinking Historically: Educating Students for the Twenty-First Century (Toronto: University of Toronto Press, 2008), 39-52;62-74; 87-103; 112-128; 142-161.

${ }^{7}$ Alan Booth, Teaching History at University (London: Routledge, 2003), 22-28; QQA Membership, Subject Benchmarking Group: History (December 2019), 9-10; Jennifer Clark and Adele Nye, "The Three Contexts of Writing about History Teaching" in Jennifer Clark and Adele Nye, eds., Teaching the Discipline of History in the Age of Standards (Singapore: Springer, 2018), 6-8.

${ }^{8}$ Jennifer Clark and Adele Nye, "Surprise Me! The (Im)possiblites of Agency and Creativity within the Standards Framework of History Education," Educational Philosophy and Theory 49, no. 6 (2017), 666-668.
} 
case involved a son of former Jacobite and turned enslaver Sir John Wedderburn against the enslaved Joseph Knight, resulting in a victory for Knight which led to the non-recognition of slavery under Scots law.

\section{Building Confidence and Independence: Students and Primary Evidence}

At upper levels in a university degree program, students are expected to use more primary source materials and to use these sources to inform their secondary reading. There is also a progression toward allowing students to freely explore primary sources within their own individual small-scale projects, moving toward independent learning. From a teaching perspective, it marks a significant shift from lecturing toward continuous coursework. ${ }^{9}$ In the spring of 2016, as I was marking essays and noticed a discrepancy in the number of primary sources that students were using, I became perplexed and concerned. I had provided a long list of primary sources with the course materials; these sources were accessible online, and physical copies were to be found easily within the library. Students were confident enough to tackle source material in class discussions, and some had even expressed enthusiasm for primary sources. So, what was the problem? After reviewing the essays, I realized that many of the students were comfortable extracting primary quotations from secondary sources as these quotations were provided with some form of context. I thought about this further and, putting myself in the students' position, realized that it was commonplace for them to analyze source material in class without any written context in class discussions beyond author, publication, and date. As a group they would collectively analyze the source, with one person offering a close analysis of the contents, another commenting on bias, and another providing some form of context. In addition, the material was already prepared for them in class; it was transcribed, ready to read, and rarely was it a full document. It made me realize that there was a lack of independence when seeking out and analyzing relevant primary source material, and this had stifled their confidence in dealing with primary sources on their own terms for their essays.

In order to try and build the students' confidence in dealing with primary sources, I designed an activity whereby, as individuals, they were to find a secondary article on the week's particular topic, analyze its contents, give a summary of its argument and, if possible, look into the background of the author and assess any bias within the article. The next part of the assignment asked students to read the footnotes, find an original primary source, and find it in its fully transcribed and printed form. In effect, I was getting the students to independently seek out primary sources of their choice, but with the "safety blanket" of the secondary source article. Once they obtained the primary source, I asked them to analyze it as they would do in class, but as an individual exercise. To bring the two elements of the assignment together, I asked the students to reflect on how the author had used the primary source in their secondary source article. The results of this exercise were presented in front of the class. As the weeks progressed, the class was independently expanding their knowledge of both primary and secondary sources in the field, and they were also learning the different ways historians integrate primary sources into their secondary analyses. As with all experiments in teaching, I was not sure if this exercise would have the desired result. However, to my delight and in contrast to the previous year, there was a far greater consultation of primary sources in the students' essays. Two students had even consulted manuscript sources in the university's special collections which confirmed that the assessment had achieved its aims.

\section{In Defense of the Duke of Cumberland: Teaching Historical Empathy}

The second activity focused on developing students' skills in historical empathy by testing their ability to judge an event or an individual's actions within the context of their time. It has been argued that this is a powerful way to develop historical understanding in undergraduate classes. ${ }^{10}$ For this exercise we had an open

\footnotetext{
${ }^{9}$ Geoff Timmins, Keith Vernon, and Christine Kinealy, Teaching \& Learning History (SAGE Publications Ltd: London, 2005), 54-65.

${ }^{10}$ Stuart J. Foster and Elizabeth Anne Yeager, "The Role of Empathy in the Development of Historical Understanding," International Journal of Social Education 13, no. 1 (1998): 1-7; Elizabeth Anne Yeager, Stuart J. Foster, Sean D Malley, Thom Anderson, and James Morris III, "Why People in the Past Acted the Way They Did: An Exploratory Study in Historical Empathy,"
} 
discussion and debate over the actions of William Augustus, Duke of Cumberland, and his men in the aftermath of Culloden. This is a well-known controversial episode in eighteenth century British history. Since the middle of the twentieth century, debate has raged over the British army's conduct under the command of William Augustus, Duke of Cumberland. Historians such as John Prebble, Murray Pittock, and Bruce Lenman argue that the British army did indeed carry out atrocities in the aftermath of Culloden. Most recently, Stuart Reid and Jonathan Oates have argued that Cumberland operated within the standards of war at the time and refute the accusations of genocide. ${ }^{11}$ I decided to bring this heated debate into the classroom.

The format of the discussion was framed around putting William Augustus, Duke of Cumberland, on trial for potential war crimes. I acted as Cumberland's defense attorney, which drew raised eyebrows and folded arms from the students. A handful of the students were from parts of the Scottish Highlands where Cumberland and his men scoured for and killed Jacobites in arms. These students in particular were surprised and repulsed that a defense in favor of "Butcher Cumberland" could even be constructed-such was the strength of feeling against Cumberland in their own local areas fuelled by folk memory passed down from generation to generation. The students knew that I, too, had my own biases and folk memory to confront before assessing the evidence for and against Cumberland and his men. By this stage in the course, it was widely known amongst the students that my great uncle (seven times removed) was a high-profile Jacobite who was executed on Kennington Common in London in 1746, and I had other direct Jacobite ancestors who had founded Scalan Seminary in the Cairngorms, which was burnt to the ground in the aftermath of the ' 45 by Cumberland's troops. ${ }^{12}$ By acting as Cumberland's defense in the trial, I led by example, showing that in order to develop a sense of historical empathy, we have to be aware of our own conscious and possible unconscious biases by removing ourselves from our own identities when assessing and considering a wide spectrum of evidence based on the reality of eighteenth-century warfare.

I then invited students in the room to put forward a counter argument that the Duke of Cumberland was indeed guilty of war crimes. Here stories emerged from local history in various parts of the Highlands, around Inverness, Fort Augustus, and Lochaber of the alleged atrocities that Cumberland and his men were said to have committed. When I asked the students the root of some of these stories, some had been taught them at school, some had been taken from local history books, others had been passed down through the family. Others were naturally ill disposed toward Cumberland based on his infamous reputation in Scotland alone. If someone is known as "Butcher Cumberland" throughout the Highlands, it must be justified, they reasoned. During our debate we broadly fleshed out the main points of the historiographical debate over the actions of the Duke of Cumberland and his men.

However, it did not end there, as we collectively peered behind these various stands and arguments on Cumberland. I was very keen for students to develop skills in evaluating historians' work in a similar way to primary source materials. In other words, I wanted students to read historians' works in the same way as they would read primary sources. In doing so, it would show that despite the primary evidence presented, historians do have conscious and unconscious biases of their own that feed into their analyses of particular events and people. We focused on Stuart Reid, a non- academic historian who is nonetheless a highly respected military historian. He is well-known for being one of Cumberland's most ardent defenders. We explored his Wikipedia entry together, which detailed that Stuart Reid was a Scot living in England and had ancestry who had fought at Culloden. ${ }^{13}$ I then asked a key question - what information on this page would be central to informing his position on Cumberland? One student put forward the correct answer, that Stuart Reid had served in the British Army. I asked how this might impact upon his perspective. Another student suggested that he may still be loyal

\footnotetext{
International Journal of Social Education 13, no. 1 (1998): 8-24.

${ }^{11}$ John Prebble, Culloden (PIMLICO: London, 1961),114-285; Murray Pittock, Great Battles: Culloden (Oxford University Press: Oxford, 2016), 99-115; Bruce Lenman, The Jacobite Risings in Britain 1689-1746 (Scottish Cultural Press: Aberdeen, 1995), 260-282; Stuart Reid, 1745: A Military History of the Last Jacobite Rising (Da Capo Press: Staplehurst, 1996), 173-182; Jonathan Oates, Sweet William or The Butcher? (Pen and Sword Military: Barnsley, 2008), 158-163.

${ }^{12}$ John Watts, Scalan: The Forbidden College: 1716-1799 (East Linton: Tuckwell Press, 1999), 94-95.

${ }^{13}$ Wikipedia, Stuart Reid (Scottish Historical Writer), https://en.wikipedia.org/wiki/Stuart_Reid_(Scottish_historical_writer)
} 
to the British army, which was a fair point, as Cumberland had commanded the British army at Culloden. I further suggested that, as a former serving soldier, Reid was the only one of our historians who had served in active combat in various war zones and this was key to informing his work on Cumberland. Reid understood the complexity and difficulty of such counter insurgency operations, the chain of command, military-civil relations, the thin lines between law, order, and oppression. At the end of the seminar, some students (but not all) had left the room convinced that William Augustus, Duke of Cumberland was not as bad as he has been remembered in recent popular memory. Students were far more aware of historical empathy, the biases of both primary and secondary sources, and the changing perspectives surrounding the Duke of Cumberland's reputation since the eighteenth century.

\section{Progress or Decline? The Jacobites and Slavery}

The third activity geared toward skills focused on the ability to detect continuity and change but also to assess progress and decline. I was keen for students to explore the "afterlife" of the Jacobite movement as exiles went to Europe, Russia, and the Americas. In our penultimate seminar, I felt that it was important for the students to understand the connection between the Jacobites and the Atlantic slave trade. This was in 2016, long before the Black Lives Matters protests had engulfed the UK and USA in 2020. In 2016, there was already a growing awareness in Scotland of its links with the slave trade with a campaign calling for the full recognition of the tobacco and sugar trades in Glasgow and its links with slavery in North America and the Caribbean. ${ }^{14}$ Nathaniel Davis, a scholar based in the UK, has argued that in teaching transatlantic slavery we should move beyond discussions about short term reasons for its abolition and emancipation by fitting the discussion in much a broader context and in a longer time span. ${ }^{15}$ Here we were connecting the commonly known narrative of Jacobitism with its lesser-known connections with the transatlantic slave trade.

In class we examined the story of Joseph Knight, an enslaved person who came to Scotland under the ownership of a son of an executed Jacobite who became an enslaver, Sir John Wedderburn. Joseph Knight took his enslaver to court in Scotland and won, leading to the non-recognition of slavery in Scotland. Joseph Knight became a free man who lived out the rest of his days in Scotland. ${ }^{16}$

My reason for introducing the students to such a story was because it was a curious source of contradictions especially as the origins of the story lie within the Jacobite movement itself. Not only does the Jacobite story continue after Culloden, but I wanted to pour cold water over any sense of sympathy or romance that the students may have had for the Jacobites. Many of the Outlander fans in the class were horrified and shocked at the suggestion that had Jamie Fraser been sent to the Caribbean as an indentured slave, it was likely that he would have become a rich enslaver! However, I was keen for the students to explore the words, "freedom," "oppression," and "liberty" within the context of Jacobitism and within the context of the slave trade. How was it that a man who had fought for the Jacobite movement to free Scotland and its people from the Act of Union 1707, could then produce a son who became an enslaver? How could a man who saw the Gaelic culture, along with the Catholic and Episcopalian faiths destroyed, then destroy the lives of others? The students were asked to dramatize the court case between Sir John Wedderburn and Joseph Knight. The case notes allowed the students to see the positions of both parties as they were reported in court. This allowed students to hear both voices, the enslaved and the enslaver, in this landmark court case. It also allowed them to assess continuity and change

\footnotetext{
${ }^{14}$ Julie Gilbert, "Glasgow's Shameful Link to the Slave Trade Remembered on International Slavery Day," Glasgow Live 23 (August 2016), https://www.glasgowlive.co.uk/news/glasgow-news/glasgows-shameful-link-slave-trade-11790114; "Fresh Call for Memorial and Museum Recognizing Scotland's Slave-Trade Links," The National 4 October 2016, https://www.thenational.scot/ news/14896348.fresh-call-for-memorial-and-museum-recognising-scotlands-slave-trade-links/

${ }^{15}$ Nathaniel Davies, "Staying with the Shot: Shaping the Question, Lengthening the Narrative, and Broadening the Meaning of Transatlantic Slavery," Teaching History 80 (2020): 21-31.

${ }^{16}$ James Robertson, Joseph Knight (Harpercollins: London, 2003); Scottish Court of Session, Decisions of the Court of Session from January 1778 to December 1781 (Edinburgh, 1791), see No III 15 January 1778, “Joseph Knight, a Negro Against John Wedderburn," 5-9.
} 
in the meaning of the terms "liberty," "oppression," and "freedom" in both contexts and see the contradictions, limitations, and complexities of the Jacobite movement in a new light. It had successfully disrupted the familiar perspectives about the decline of the Jacobite movement and opened up a debate about the notion of progress in the context of slave ownership and empire. Students enjoyed participating in the dramatization but also appreciated a more balanced approach to the Jacobite movement, especially those students from minority backgrounds. ${ }^{17}$

\section{Beyond Classroom Walls: \#Team Jacobite and \#Team Hanoverian Go Global}

It is now recognized that millennials learn differently from previous generations due to the emergence of the internet and the new media. This generation has seamlessly used technology in all aspects of their life, and there have been calls to update teaching methods and history instruction to accommodate these developments and new learning preferences. Suggested activities in class include recreating events on Twitter as if they are happening in real time, the critical analysis of Tweets, feedback on presentations, and interclass support. Another suggestion is for a class discussion relayed on Twitter which invites those from outside the classroom to participate in. ${ }^{18}$ This is something I did in the final week of the course with the agreement of the students. I was aware that tweeting conference papers was becoming commonplace in academia and wondered if this idea could be transferred into the classroom.

The final class discussion of the course was used as a way to reflect upon the course as a whole and take the long view on the Jacobite movement. However, in contrast to previous class discussions, we decided to post our discussion on Twitter, allowing the students to not only discuss the wider debates and consolidate their learning, but also to take pride in their learning by showcasing it to the outside world. I treated them as newly minted experts in the field by tagging influential and significant Jacobite scholars, whose books the students had been reading throughout the course, in our online debate. I had decided to split the class into two parts, \#TeamHanoverian and \#TeamJacobite. We used my own academic twitter account as the outlet to communicate to the academic community. Students who had their own Twitter accounts logged in, too, and supported their team with likes and comments. Framed similar to a school debate, there were opening shots and statements. I opened the discussion by declaring, "This House contends that the Jacobite Cause was an inevitable failure - do you agree?" 19 \#TeamJacobite stated, "Jacobites posed a direct threat to the Hanoverian monarchy for many years." ${ }^{20}$ \#TeamHanoverian opened their case by stating, "Jacobitism is a romantic idea rooted in a forlorn cause." ${ }^{21}$ It was an entirely student driven discussion with key points about the Jacobites and Hanoverians going back and forth online. The discussion was relaxed, fun, and interactive with comments from the leading academics. The students enjoyed this discussion immensely. ${ }^{22}$ It demonstrated the power of social media to consolidate learning by allowing the students to become independent learners through debate whilst having fun in the process.

\footnotetext{
${ }^{17}$ As reported in annual course evaluation report, 2016.

${ }^{18}$ Johannes Ahrenfelt, "Immersive Learning in the History Classroom: How Social Media Can Help Meet the Expectations of a New Generation of Learners," in Using New Technologies to Enhance Teaching and Learning in History, ed. Terry Hayden (Routledge: Abingdon, 2013): 143-146; Kelly, Teaching History in the Digital Age, 11; 51; David R. Arndale, "Using Social Media Tools for Academic Support and Enrichment in the Classroom," NADE Digest 9, no. 1 (2017): 8-12; Kathleen P. King, "Voice, Empowerment and Impact: Using Digital Technologies in the Classroom," The Professor's Guide to Taming Technology, eds. Kathleen P. King and Thomas Cox (Charlotte, NC: Information Age Publishing, Inc., 2011): 15-30.

${ }^{19}$ Twitter @kirsteenmm, “This House Contents that the Jacobite Cause was an Inevitable Failure,” https://twitter.com/kirsteenMM/ status/798480083119996928?s=20

${ }^{20}$ Twitter@kirsteenmm, “Opening Case \#TeamJacobite,” https://witter.com/kirsteenMM/status/799575849716563968?s=20

${ }^{21}$ Twitter@kirsteenmm, “Opening Case \#TeamHanoverian,” https://witter.com/kirsteenMM/status/799576222565076992?s=20

${ }^{22}$ Conclusions drawn from annual student course report, 2016.
} 


\section{Towards Interactive Student Centered Learning: Designing an Online Jacobite Course for the Twenty-First Century}

As the pandemic began in March 2020, many UK universities were forced to set up fully online versions of previously face-to-face courses. During this process, lectures were recorded and posted online and tutorials and seminars were conducted through Zoom and Microsoft Teams as online group meetings. In many respects, this online environment tried to replicate the face-to-face environment rather than significantly change teaching methods or instruction. However, some scholars have now questioned the efficacy of traditional teaching structures which have been in place for hundreds of years. Indeed, the skills-based approach to history teaching allows us to revisit and reflect upon age old methods and standards and question whether they teach the skills required in the twenty-first century. ${ }^{23}$

In 2020, I created a sample module for an online course using the latest methods in online teaching, digital humanities, and history pedagogy. For this exercise, I decided to create an online module on the Duke of Cumberland and the British Army's actions after Culloden. This was very much based on the class I had conducted on historical empathy on a face-to-face basis. However, I avoided setting up a like-for-like online replica of the face-to-face class that would have consisted of an online lecture and an online discussion. Instead, I took a whole new approach to designing a course based around the new technologies and the new media that focused squarely on developing skills sets which would enable students to think critically. The differences in the face-to-face course and the digital version are summarized in the table below:

Table 1 - Traditional Teaching/Content and Online Skills-Based Teaching

\begin{tabular}{|l|l|}
\hline Face-to-Face & Digital \\
\hline $\begin{array}{l}\text { Nineteenth century methods; lectures and } \\
\text { seminar discussions. }\end{array}$ & $\begin{array}{l}\text { Twenty-first century approaches focusing on the completion of } \\
\text { tasks which develop critical thinking skills. }\end{array}$ \\
\hline $\begin{array}{l}\text { Takes place on a physical campus and within a } \\
\text { physical classroom at a prescribed time. }\end{array}$ & $\begin{array}{l}\text { Fully online and asynchronous; no physical classroom and } \\
\text { students can complete the tasks in their own time as long as they } \\
\text { meet the final deadline. }\end{array}$ \\
\hline Students discuss text-based sources. & $\begin{array}{l}\text { Students work with a variety of different sources; audible, images, } \\
\text { and films. This caters to a wider variety of different learning } \\
\text { preferences. It allows for greater accessibility options for students } \\
\text { with certain challenges. }\end{array}$ \\
\hline $\begin{array}{l}\text { Nineteenth century assessments; essays and } \\
\text { exams. These follow academic conventions with } \\
\text { limited transferable benefit outside academia. }\end{array}$ & $\begin{array}{l}\text { Focuses on the development of generic critical thinking skills } \\
\text { through "doing history" These skills are transferable to the } \\
\text { workplace and can be used more widely as a life skill applicable in } \\
\text { a wide range of circumstances. }\end{array}$ \\
\hline
\end{tabular}

Under this new course model, the discussion moves from being teacher-led to student-led as students independently work through a series of tasks. Students work through each of the tasks within the module, effectively teaching themselves after the completion of each task. ${ }^{24}$ Students can be drawn from across the globe and work together across time zones using a number of different devices such as laptops, other mobile devices, and desktops. It even allows students to complete the tasks whilst they are travelling from place to place. It is envisaged that the whole course would not have any fixed or scheduled classes, as is the case in a traditional setting. Instead, the class would have a series of flexible deadlines for the completion of tasks, as long as the

\footnotetext{
${ }^{23}$ Nastaran Peimani and Hesam Kamalipour, "Online Education and the COVID-19 Outbreak: A Case Study of Online Teaching During Lockdown," Education Sciences 11 (2021); Paul Feldman, "Digital Transformation in Education: From Vision to Practice during the Pandemic," in Languages at Work, Competent Multilinguals, and the Pedagogical challenges of COVID-19, A. Plutino and E. Polisca, eds. Research-publishing.net, https://eric.ed.gov/?id=ED612178

${ }^{24}$ Kirsteen M. MacKenzie, “Online Portfolio,” https://historianremote.net/
} 
students meet the final deadline for the course, allowing students to complete the course at their own pace. This allows for a flexibility which caters for a wider range of students that now exist in the twenty-first century such as working parents, single parents, mature students in full-time employment, or people with various disabilities and chronic illness who would otherwise be barred or inhibited from a traditional university education. The prototype for the module includes videos, images, and sounds related to Cumberland's actions after Culloden. This approach brings history alive, beyond black ink on a white piece of paper. For example, students use Google to explore the popular reputation of Cumberland and to critically evaluate the differences of opinion and information that they find. They are also encouraged to assess paintings in great detail and absorb the sounds of English and Scottish Gaelic folk music as they listen to authentic recreations of eighteenth-century folk songs. The module dispenses with traditional modes of assessment and focuses on critical thinking skills, such as empathy, evaluation and assessment of evidence, and an appreciation of cultural difference and conflict. These skills are essential to living in today's society and highlight the value of teaching eighteenth century history, or indeed any history, to positively shape people's lives thereby contributing to a healthy and happy society and democracy.

\section{Conclusion}

From 2015 to 2021 I have significantly evolved in my approach to teaching eighteenth century history. I have moved from designing knowledge-based courses to skill-based courses. I have also experimented with new student assessments to solve problems or issues in student learning. I have focused on developing defined skills which all historians use regardless of specialization or field of interest. I have tried to teach historical empathy through leading by example and encouraging students to refrain from judging even one of the most unpopular figures from eighteenth century history too harshly and encouraging them to explore all sides of the historical debate regardless of personal biases or established reputation. My students began to view historians of the Jacobite wars as minefields of potential biases based on the historians' backgrounds. I introduced marginalized and often forgotten voices from history and in doing so disrupted the romantic image of the Jacobite exile. With this approach I hope that I showed my students what historians should be thinking and doing in the twenty-first century.

I have also made a concerted effort to integrate and use the new media in my university teaching as I recognize that a new generation of students has a different approach to learning than previous generations. Social media was used to consolidate learning through interactivity and fun. I see the new media and the digital technologies as being essential tools in my future as a history professional whether it be online course design and assessment or in the classroom face-to-face with the students. There are lessons here that can be applied beyond my own classroom. I have shown how easy it is to integrate the new technologies into a traditional face-to-face environment. We can frame student activities around developing historical skills whilst keeping the traditional seminar approaches to student learning. This article has also highlighted the importance and benefits of acknowledging the diverse student backgrounds in our classrooms and how this can help us build a more inclusive environment as well as providing the opportunity to embrace new approaches to our course content. Traditional forms of teaching eighteenth century history have fundamentally been challenged by the new technologies and pedagogical approaches. We have undergone significant evolutionary change. The way we teach eighteenth century studies today is far removed from the hallowed halls filled with men in the 1940s. 